\title{
Inhaled budesonide for chronic wheezing under 18 months of age
}

\author{
V Noble, N R Ruggins, M L Everard, A D Milner
}

Children's Respiratory

Unit,

Queen's Medical Centre, Nottingham NG7 2UH $\checkmark$ Noble

N R Ruggins

M L Everard

A D Milner

Correspondence to:

Dr Noble.

Accepted 30 October 1991

\begin{abstract}
The role of budesonide in controlling chest symptoms in infants was assessed. It was administered from a metered dose inhaler into a large volume spacer (Nebuhaler) with attached Laerdal mask. Twenty nine infants were recruited into a double blind crossover trial. Five defaulted. The remaining 24 (mean age 11 months) were assessed for the tolerance of the device, adverse effects, treatment failures, parental opinion, and daily symptom and treatment records. Twenty tolerated the modified Nebuhaler. One developed meningitis on placebo. Two experienced exacerbations on placebo. Eleven of 18 parents whose children completed the maximum treatment preferred budesonide to placebo and one preferred placebo. Mean symptom scores on budesonide were better than on placebo for the 15 children with complete symptom records. Fewer bronchodilator doses were used while taking budesonide. Our findings indicate that budesonide given in this way is an effective treatment for infants who may need prophylaxis for their wheezing.
\end{abstract}

Although very common, wheezing has proved very resistant to treatment in infancy. ${ }^{1}$ There is little evidence that oral therapy with $\beta_{2}$ stimu-

Table 1 Details of infants enrolled

\begin{tabular}{|c|c|c|c|c|c|c|}
\hline $\begin{array}{l}\text { Subject } \\
\text { No }\end{array}$ & $\begin{array}{l}\text { Age } \\
\text { (months) }\end{array}$ & Sex & $\begin{array}{l}\text { Gestation } \\
\text { (weeks) }\end{array}$ & $\begin{array}{l}\text { Birth } \\
\text { weight } \\
(g)\end{array}$ & $\begin{array}{l}\text { Neonatal } \\
\text { respiratory } \\
\text { problems }\end{array}$ & $\begin{array}{l}\text { Atopic first } \\
\text { degree } \\
\text { relatives }\end{array}$ \\
\hline $\begin{array}{r}1 \\
2 \\
3 \\
4 \\
5 \\
6 \\
7 \\
8 \\
9 \\
10 \\
11 \\
12 \\
13 \\
14 \\
15 \\
16 \\
17 \\
18 \\
19 \\
20 \\
21 \\
22 \\
23 \\
24 \\
25^{*} \\
26^{*} \\
27^{*} \\
28^{*} \\
29^{*}\end{array}$ & $\begin{array}{r}9 \cdot 3 \\
11 \cdot 0 \\
17 \cdot 4 \\
4 \cdot 1 \\
12 \cdot 4 \\
16 \cdot 4 \\
7 \cdot 0 \\
11 \cdot 5 \\
12 \cdot 5 \\
15 \cdot 1 \\
12 \cdot 8 \\
13 \cdot 1 \\
5 \cdot 9 \\
12 \cdot 1 \\
10 \cdot 3 \\
11 \cdot 1 \\
17 \cdot 2 \\
6 \cdot 5 \\
9 \cdot 4 \\
10 \cdot 6 \\
9 \cdot 0 \\
12 \cdot 1 \\
7 \cdot 1 \\
17 \cdot 0 \\
13 \cdot 7 \\
12 \cdot 4 \\
6 \cdot 1 \\
15 \cdot 0 \\
7 \cdot 5\end{array}$ & $\begin{array}{l}\mathbf{F} \\
\mathbf{F} \\
M \\
M \\
M \\
M \\
M \\
M \\
M \\
M \\
M \\
M \\
F \\
F \\
M \\
M \\
M \\
M \\
M \\
M \\
M \\
F \\
F \\
M \\
M \\
F \\
M \\
M \\
M\end{array}$ & $\begin{array}{l}37 \\
40 \\
40 \\
40 \\
36 \\
40 \\
30 \\
27 \\
38 \\
35 \\
38 \\
40 \\
36 \\
40 \\
40 \\
40 \\
32 \\
38 \\
32 \\
36 \\
34 \\
42 \\
40 \\
38 \\
40 \\
37 \\
43 \\
40 \\
40\end{array}$ & $\begin{array}{l}3880 \\
2950 \\
3400 \\
3660 \\
3090 \\
2840 \\
1080 \\
1070 \\
2890 \\
1660 \\
3520 \\
2890 \\
2890 \\
3150 \\
3910 \\
3200 \\
1550 \\
2980 \\
1360 \\
2840 \\
2100 \\
3150 \\
3150 \\
3060 \\
3560 \\
3130 \\
3430 \\
3570 \\
3350\end{array}$ & $\begin{array}{l}\text { None } \\
\text { None } \\
\text { None } \\
\text { None } \\
\text { None } \\
\text { None } \\
\text { Pneumonia } \\
\text { BPD } \\
\text { None } \\
\text { None } \\
\text { None } \\
\text { None } \\
\text { None } \\
\text { None } \\
\text { None } \\
\text { None } \\
\text { BPD } \\
\text { None } \\
\text { None } \\
\text { None } \\
\text { RDS } \\
\text { None } \\
\text { None } \\
\text { None } \\
\text { None } \\
\text { None } \\
\text { None } \\
\text { None } \\
\text { None }\end{array}$ & $\begin{array}{l}\text { Yes } \\
\text { Yes } \\
\text { Yes } \\
\text { No } \\
\text { No } \\
\text { Yes } \\
\text { No } \\
\text { Yes } \\
\text { N/A } \\
\text { No } \\
\text { Yes } \\
\text { No } \\
\text { Yes } \\
\text { Yes } \\
\text { No } \\
\text { Yes } \\
\text { Yes } \\
\text { Yes } \\
\text { No } \\
\text { Yes } \\
\text { Yes } \\
\text { Yes } \\
\text { Yes } \\
\text { No } \\
\text { Yes } \\
\text { No } \\
\text { Yes } \\
\text { No } \\
\text { No }\end{array}$ \\
\hline
\end{tabular}

*Subjects 25-29 defaulted from follow up.

N/A, result not available; BPD, bronchopulmonary dysplasia; RDS, respiratory distress syndrome.

lants, ${ }^{2}$ theophylline ${ }^{3}$ or even steroids, ${ }^{4}$ has any effect on the natural history of wheezing episodes in the first year of life. There remains considerable dispute whether inhaled $\beta_{2}$ stimulants improve lung function in infancy, ${ }^{5-8}$ and only studies using ipratropium bromide have consistently documented a response, and then in less than $50 \%$ of infants. ${ }^{9-11}$ Nebulised sodium cromoglycate does not appear to have a useful prophylactic effect until the child is over the age of 1 year. ${ }^{1012}$

There is however, some evidence that inhaled steroids may be of value. Studies on the nebulised solutions have been disappointing, probably due to formulation problems. ${ }^{13}$ This has been found particularly with beclomethasone suspension. It has been reported that less than $20 \%$ of the active drug is in particles less than $5 \mu \mathrm{m}$ in diameter (a size likely to reach the smaller airways) when beclomethasone is nebulised using a standard device. ${ }^{14}$ In order to overcome these problems, we have developed a face mask (Laerdal size 2) and spacer (Nebuhaler, Astra) metered dose inhaler delivery system. ${ }^{15}$

In this paper, we report the results of a double blind, crossover study investigating the effects of inhaled budesonide in wheezy infants who were less than 18 months of age.

\section{Subjects}

Twenty nine children aged 4 to 17 months (mean 11 months) were enrolled into the study (table 1). They had a history of recurrent cough and/or wheeze for greater than two months and for three or more days a week. They were each heard to wheeze on at least one occasion by a doctor. Specific conditions which could lead to recurrent respiratory symptoms, such as heart disease, cystic fibrosis, and gastro-oesophageal reflux, were excluded by clinical assessment and investigations as indicated.

\section{Methods}

The trial was a randomised, double blind, placebo controlled, crossover study, approved by the hospital's ethical committee. Children were referred for consideration for entry into the study by paediatricians at the Queen's Medical Centre, Nottingham, and at King's Mill Hospital, Mansfield. On referral parents were instructed to keep a symptom diary. The parameters of breathlessness, wheeze, and cough during the night and the day were given a score of between 0 and 3 on an arbitrary ordinal scale, 0 for no symptoms and 3 for severe symptoms. They were also asked to keep a record of the 
amount of bronchodilator treatment they administered to their child as they felt necessary. If a child wasn't receiving a bronchodilator at the time of referral, they were given an ipratropium bromide metered dose inhaler with a coffee cup spacer to use. On review three weeks later, if they met the criteria for inclusion into the study, written, informed parental consent was obtained. The children were randomised to one of two treatment sequences starting with either budesonide or placebo. They were then shown how to use the modified Nebuhaler (which has previously been described ${ }^{15}$ ) and asked to continue keeping a symptom diary.

Three puffs of budesonide equivalent to 150 $\mu \mathrm{g}$, or three puffs of placebo were administered into the Nebuhaler with the valve closed. The Nebuhaler was then tipped downwards to open the valve by gravity and the mask was applied to the child's face to provide an airtight seal. The parents were asked to keep it in position for 10 to 20 seconds and on removal were instructed to wipe their child's face to remove excess aerosol. The treatment was given twice daily. If a child accepted the mask particularly poorly, the parents were instructed to administer the treatment in the same manner but when their child was asleep. If the child still would not accept the mask, this was regarded as intolerance of the device and the child was withdrawn from further participation in the study. Hospital review was undertaken every three weeks for a clinical assessment and retrieval of the current symptom diary and aerosol canister for weighing. A new diary and canister were then supplied. At six weeks the children were changed onto the opposite treatment.

Symptom scores and additional treatment data were analysed for the second three weeks of each six week treatment period. This was to allow for establishment of the treatment or a washout period during the first three weeks of each six week period. Symptom scores were analysed individually for each parameter and also summated to give a 24 hour total symptom score.

Children whose clinical condition deteriorated significantly, necessitating a breaking of the code, were to be regarded as treatment failures and withdrawn from further participation.

Finally, we asked the parents for their preference between the two treatments before the code was broken.

\section{ANALYSIS}

Symptom scores were analysed using the MannWhitney $U$ test to compare the differences between those who started on placebo and those who started on budesonide. Parental preference was analysed by Fisher's exact test.

\section{Results}

Twenty nine children were enrolled into the study (table 1). Five defaulted from follow up before completion and resisted repeated requests to reattend. This left a study group of 24 children aged 4-17 months (mean 11 months) who could be assessed.

\section{TOLERANCE}

Twenty out of the 24 children $(83 \%)$ were able to tolerate the modified Nebuhaler. Three $(12.5 \%)$ would only do so while asleep. Four (17\%) would not even tolerate the device while asleep and could proceed no further in the trial. They were withdrawn at the end of the first three week period.

There were two treatment failures, both of whom were on placebo at the time. One of these had an exacerbation of his symptoms with an upper respiratory infection and was prescribed oral steroids by his family doctor. He showed no response to the prednisolone or subsequently to budesonide. The other child relapsed in the final period with no precipitating factors apart from the change in treatment from budesonide to placebo. He made a good recovery on restarting budesonide. One child developed Haemophilus influenzae meningitis while receiving the placebo treatment, having not previously received budesonide. He was withdrawn when diagnosis of meningitis was made.

\section{PREFERENCE}

Eighteen sets of parents (including one of the two whose children were failures on placebo treatment, and who started but failed to complete the final three weeks), were in a position to express a preference at the end of the study. Eleven $(61 \%)$ preferred budesonide to placebo, and one set preferred placebo $(p=0.01)$. Five $(28 \%)$ thought that neither treatment made a difference and one $(5 \cdot 5 \%)$ thought both treatments were effective. There was no significant treatment order effect (period effect, $p=0 \cdot 8$; carry over effect, $\mathrm{p}=0.5$ ).

\section{SYMPTOMS}

Fifteen children had diaries complete enough to be suitable for analysis. Individual trends are shown in the figure. The mean total 24 hour symptom score and the mean individual symptom score parameters were better on budesonide (table 2). All symptom scores apart from nocturnal wheeze and cough showed a significant difference. This effect was also apparently independent of treatment order (period effect, $p=0 \cdot 4$; carry over effect, $p=0.5$ ).

Less rescue bronchodilator was used while on budesonide, but as children varied in which

Table 2 Symptom diary analysis

\begin{tabular}{|c|c|c|}
\hline $\begin{array}{l}\text { Score } \\
\text { parameter }\end{array}$ & $\begin{array}{l}\text { Mean placebo } \\
\text { - budesonide difference } \\
\text { ( } 95 \% \text { confidence interval) }\end{array}$ & $\stackrel{p}{\text { Value }}$ \\
\hline $\begin{array}{l}\text { Breathlessness } \\
\text { Night } \\
\text { Day } \\
\text { Wheeze }\end{array}$ & $\begin{array}{l}0.21(0.05 \text { to } 0.37) \\
0.29(0.05 \text { to } 0.53)\end{array}$ & $\begin{array}{l}0.02 \\
0.02\end{array}$ \\
\hline $\begin{array}{l}\text { Wheeze } \\
\text { Night } \\
\text { Day }\end{array}$ & $\begin{array}{l}0.38(-0.06 \text { to } 0.82) \\
0.53(0.10 \text { to } 0.96)\end{array}$ & $\begin{array}{l}0.13 \\
0.03\end{array}$ \\
\hline $\begin{array}{l}\text { Cough } \\
\text { Night } \\
\text { Day }\end{array}$ & $\begin{array}{l}0.35(0.00 \text { to } 0.70) \\
0.35(0.05 \text { to } 0.65)\end{array}$ & $\begin{array}{l}0.07 \\
0.04\end{array}$ \\
\hline $\begin{array}{l}\text { Total } 24 \text { hour } \\
\text { symptom score * } \\
24 \text { hour treatment } \\
\text { score }\end{array}$ & $\begin{array}{l}2.1(0.04 \text { to } 3.8) \\
0.27(-0.06 \text { to } 0.60)\end{array}$ & $\begin{array}{l}0.03 \\
0 \cdot 12\end{array}$ \\
\hline
\end{tabular}

\pm 2 at the $95 \%$ significance level $=0 \cdot 26$. 


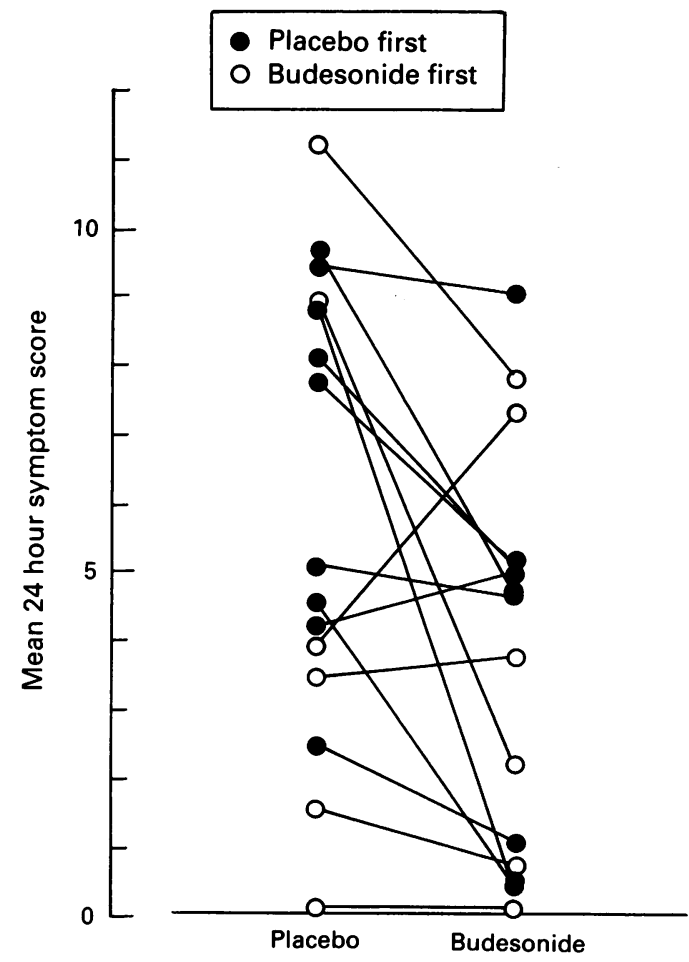

Symptom score according study phase for individual subjects.

bronchodilator they were given, this reduction was not significant (table 2 ).

There was no difference between the group who responded to treatment and those who did not in terms of family history of atopy. Three of the non-responders were ventilated in the newborn period. Two of these had respiratory distress syndrome and subsequent bronchopulmonary dysplasia, the other had pneumonia. One of those who responded had respiratory distress syndrome but was not ventilated.

\section{Discussion}

The use of a large volume spacer with attached face mask to administer aerosols to children was first suggested by Freigang as long ago as $1977 .^{16}$ Even though the same author and many others have documented the beneficial effects of steroid aerosols in preschool children, ${ }^{17-19}$ few studies of their effects in infancy have been reported. We have shown that it can be effective in administering inhaled steroids to a group of young infants who may need prophylaxis for persistent symptoms, and for whom there is no established, reliable alternative treatment. Recent work in our department has shown that this method of administering inhaled steroids is particularly suited to infants' tidal volumes. The dose of budesonide inhaled per kilogram body weight from metered dose inhaler using a Nebuhaler and face mask is then considerably greater compared to the dose inhaled by an adult using a Nebuhaler. The dose thus delivered, should be sufficient to produce a response if the drug is appropriate to this age group.

Approximately half of our study group of 24 were treated successfully, comprising three quarters who could tolerate the modified Nebuhaler, two thirds of whom responded to the treatment given in this way. Although we found no statistically significant treatment order effects, it may be that the washout period of three weeks was not quite adequate, thus tending to minimise the recorded symptom score difference between budesonide and placebo when budesonide was administered first. This was suggested by the observation that the group who received budesonide first had a mean improvement in symptom scores about half that of the other group. In addition, two sets of parents in the 'budesonide first' group implied that they felt the placebo had some activity: one of these preferred placebo the other felt that both treatments helped. It may be that the effects of topical steroids persist for several months and would therefore still be present after only a three week washout. ${ }^{20}$ Our treatment period of six weeks may have been too short to show the maximum effect of budesonide in all cases. In their study, Bisgaard and colleagues saw an improvement up to eight weeks after the onset of treatment before a plateau was reached. In the same study they showed inhaled budesonide to be effective when administered using a similar but more complicated adaptation of the Nebuhaler. ${ }^{21}$ They used a higher dose in a slightly older group of children. ${ }^{22}$ In a group of children of similar age to ours, however, Van Bever and colleagues were not able to demonstrate a significant improvement in symptoms using nebulised budesonide. ${ }^{23}$

The group of wheezy children in our study could not all necessarily be firmly classed as having asthma, and it was interesting to note the poor response of a subgroup of three children who had been ventilated in the newborn period. However, the small numbers involved make it impossible to draw any firm conclusions from this particular observation. In conclusion, for this age group of children in whom therapeutic options are limited, budesonide administered in this way offers a useful addition to the available range.

1 Silverman M. Bronchodilators for wheezy infants? Arch Dis Child 1984;59:84-7.

2 Tal A, Bavilski C, Yohai D, Bearman JE, Gorodischer R, Moses SW. Dexamethasone and salbutamol for acute wheezing in infants. Pediatrics 1983;71:13-8.

3 Brooks LJ, Cropp GJA. Theophylline therapy in bronchiolitis. Am 7 Dis Child 1981;135:934-6.

4 Webb MSC, Henry RL, Milner AD. Oral corticosteroids for wheezing attacks under 18 months. Arch Dis Child 1986;61: wheezing.

5 Radford $M$. Effect of salbutamol in infants with wheezy bronchitis. Arch Dis Child 1975;50:535-8.

6 Lenney W, Milner AD. At what age do bronchodilators work? Arch Dis Child 1978;53:532-4

7 O'Callaghan C, Swarbrick A, Milner AD. Paradoxical deterioration in lung function after nebulised salbutamol in wheezy infants. Lancet 1986;ii:1424-5.

8 Prendeville A, Green S, Silverman M. Airways responsiveness in wheezy infants: evidence for functional $\beta$ adrenergic receptors. Thorax 1987;42:100-4.

9 Hodges IGC, Groggins RC, Milner AD, Stokes GM. Bronchodilator effect of inhaled ipratropium bromide in wheezy toddlers. Arch Dis Child 1981;56:729-32.

10 Henry RL, Hiller EJ, Milner AD, Hodges IGC, Stokes GM Nebulised ipratropium bromide and sodium cromoglycate in the first two years of life. Arch Dis Child 1984;59:54-7.

11 Prendeville A, Green S, Silverman M. Ipratropium bromide and airways function in wheezy infants. Arch Dis Child and airways functio

12 Geller-Bernstein C, Levin S. Nebulised sodium cromoglycate in the treatment of wheezy bronchitis in infants and young children. Respiration 1982;43:294-8.

13 Webb MSC, Milner AD, Hiller EJ, Henry RL. Nebulised beclomethasone dipropionate suspension. Arch Dis Child 1986;61:1108-10. 
14 O'Callaghan C. Particle size of beclomethasone dipropionate produced by 2 nebulisers and 2 spacers. Thorax 1990;45: produced

15 O'Callaghan C, Milner AD, Swarbrick A. Spacer device with face mask attachment for giving bronchodilators to infants with asthma. $B M \mathcal{F} 1988 ; 298: 160-1$.

16 Freigang $B$. New method of beclomethasone administration to children under 4 years of age. Can Med Assoc $\mathcal{F} 1977 ; 117$ 1308-09.

17 Freigang $B$. Long term follow-up of infants and children treated with beclomethasone aerosol by a special inhalational device. Ann Allergy 1980;45:13-7.

18 Gleeson GA, Price JF. Controlled trial of budesonide given by the nebuhaler in pre-school children with asthma. $B M \mathcal{J}$ 1988;297:163-6.
19 Godfrey S, Konig P. Treatment of childhood asthma for 13 months and longer with beclomethasone dipropionate months and longer with beclomethas

20 Carlsen KH, Leegaard J, Larsen S, Ørstavik I. Nebulised Carlsen $\mathrm{KH}$, Leegaard J, Larsen S, Ørstavik I. Nebulised
beclomethasone dipropionate in recurrent obstructive episodes after acute bronchiolitis. Arch Dis Child 1988;63: 1428-33.

21 Bisgaard H, Ohlsson S. PEP-spacer: an adaptation for administration of MDI to infants. Allergy 1989;44:363-4.

22 Bisgaard H, Munck SL, Nielsen JP, Petersen JP, Ohlsson $\mathrm{SV}$. Inhaled budesonide for treatment of recurrent wheezing in early childhood. Lancet 1990;336:649-51.

23 Van Bever HP, Schuddinck L, Woiciechowski M, Steven WJ. Aerosolized budesonide in asthmatic infants. Pediat Pulmonol 1990;9:177-80.

\section{Vitamin $A$ again}

One of the most exciting recent developments in paediatrics has been the realisation that giving supplements of vitamin A to young children in developing countries might prevent enormous numbers of deaths not only from measles (see Archivist 1991: 139) but from other causes. ${ }^{1}$ It has been estimated that some 5-10 million children world wide develop xerophthalmia each year and between five and 10 times that number suffer from subclinical vitamin A deficiency, which leads to increased mortality from diarrhoeal and respiratory diseases. Trials of vitamin A supplementation in Indonesia ${ }^{2}$ and India $^{3}$ have shown reductions in preschool child mortality of between a third and half, although another trial in India ${ }^{4}$ produced negative results. Now another trial, this time from Nepal, has produced encouraging results (Keith P West Jr and colleagues, Lancet 1991; 338: 67-71).

In all 28630 children aged between 6 months and 5 years entered the trial. They lived in 261 wards in the rural plains district of Sarlahi and each ward was allocated at random to treatment or placebo, treatment consisting of vitamin $\mathrm{A}$ in a dose of 60000 retinol equivalents $(200000 \mathrm{IU})$ for children of 12 months or more and half that for those less than 12 months, given every four months. Placebo consisted of vitamin A, 300 or 150 retinol equivalents according to age, also given every four months.

Over a 12 month period of follow up mortality was 16.4 per 1000 child years in the placebo group and 11.5 per 1000 child years in the vitamin A supplemented group. Supplementation, therefore, gave a $30 \%$ reduction in mortality or a protective relative risk of $0 \cdot 7$. The benefit was seen in both sexes, at all ages within the range studied, and throughout the year and it did not seem to be affected by the child's nutritional status. Significant reductions were seen for deaths attributed to measles (relative risk $0.24)$, non-specified infections $(0.52)$, diarrhoea $(0.61)$, and malnutrition $(0.65)$ but, surprisingly, not for pneumonia.

It is estimated that vitamin A supplementation for preschool children might save over 15000 lives in Nepal each year and about a million in the whole of south Asia.

\section{ARCHIVIST}

1 McMillan JA, Oski FA. Contempo '91. Pediatrics. FAMA 1991;265:3156-8.

2 Sommer A, Tarwotjo I, Diunaedi E, et al. Impact of vitamin A supplementation on childhood mortality: a randomised controlled community trial. Lancet 1986;i: childhood $1169-73$.

3 Rahmathullah L, Underwood BA, Thulasiraj RD, et al. Reduced mortality among children in Southern India receiving a small weekly dose of vitamin A. N Engl f children in Southern $1990 ; 323: 929-35$.

4 Vijayaraghavan K, Radhalah G, Prakasam BS, et al. Effect of massive dose vitamin A on morbidity and mortality in Indian children. Lancet 1990;336:1342-5. 